\title{
Women and ljtihad:
}

\section{Towards a New Islamic Discourse}

Heba Raouf Ezzat

\section{A Scene of Polarization}

A phenomenon of extreme polarization between the Islamist and the secular camps characterizes the intellectual scene regarding social, economic, and political issues in the Arab-Islamic world. This is especially true with respect to women's issues, which are a very hotly contested terrain.

Understanding this reality clearly requires a historic overview to comprehend how this polarization occurred and map the debate between supporters of "modernity and contemporality" (al-hadatha wa-I-mu'asara) on the one hand, and supporters of "tradition and authenticity" (al-turath wal-asala) on the other. Though this is not at the heart of our research, framing it in its historical context enables us to better understand the roots and origins of the problem, in order to map the debates and foresee future courses more clearly.

The first thing one notices is the absence of an agreed upon frame of reference. The conflict here is not among intellectual streams that are standing on the same ground but have different ijtihads. 'It is a clash between two main "camps": one that claims to stand for enlightenment, an intellectual renaissance, and modernization with all its secular aspects and beliefs (in its factions from left to right). The other camp (in all its factions as well) fervently defends Islam, shari'a, tradition, and authenticity.

While the first camp approaches Islam from a distance and acknowledges that it is a religion of justice, equality, and reason, it does not proceed from it in any fundamental way and does not base itself on Islam through ijtihad around the implications of these concepts. When religion is mentioned, it is done so very briefly and without any serious engagement. The second camp tries to defend itself against accusations of backwardness by asserting the importance of technological advances, of a scientific renaissance, and of benefitting from the West with respect to material innovations. However, it has failed to engage in ijtihad, and its attempts in that respect lacked the complexity and effort required to offer an alternative model for this day and age.

One could refer to the current situation as a state of "entrenchment" where each camp stays in its corner and attacks the other: "Each party rejoices in that which is with itself" (Qur'an 23:53) The content of their mutual verbal attacks has not changed since the 1940s. Readers following this debate on many levels would notice signs of rapprochement and understanding in regular events such as the Arab Nationalist- 
Islamic Conference without this ever leading to agreement on a particular issue or offering creative solutions to this conflict. ${ }^{2}$

Arab enlightenment literature around the end of the 19th century and the beginning of the twentieth century tackled the issue of women and discussed their situation, rights, and political participation. Islamist arguments, put forward by the religious establishment, organized groups, and some Islamist thinkers came as a reaction and a concerted effort to confront "danger".

\section{Characteristics of the Islamists' Discourse on Women}

Textuality and Tradition: While the Islamic discourse has sought ijtihad on urgent issues pertaining to the economy and politics considering the nature of its relation with authority and its evolution, on the issue of women it has remained shackled by a strict adherence to the literalist interpretation of religious texts and has failed to develop an ijtihad that would deal with the circumstances, specificities, and disagreements/ uncertainties related to applying the text to real life situations. In other words, the text remained "stagnant" and binding instead of being activated or brought to life, and adapted to changing reality. Furthermore, the interpretations of many previous Islamic jurists (fuqaha') were adopted without an attempt to adapt or tailor them to the legal context, distinguishing what is constant from what differs through time and necessitates the revision of Islamic jurisprudence (figh) and religious legal rulings (fatwas). ${ }^{3}$ This led to constraining the text to past interpretations instead of liberating it to make it the basis for change and enlightenment. Thus, instead of playing an enlightening, progressive role, figh tradition worked to constrain women's rights. The focus continued to be directed towards women's exclusion, restricting them to their role within the family, and limiting their public engagement to missionary activities (da'wa) or deliberations on minute details related to worship, etc.

Historicism and Simplification: The Islamists' discourse is limited by the historical experience during the Prophet's life. It uses the Prophet's example to honor him and the participation of his female companions as an example of women's rights in Islam without showing how this example applies to the contemporary, daily situation of women. ${ }^{4}$ Moreover, many issues have been oversimplified and dealt with superficially, as is the case with women's labor: Women either have the option to work in a limited number of fields or to be housewives, without ever taking into account differences in women's abilities, their social and cultural circumstances, the difference between urban women and rural women, and so on. ${ }^{5}$ Perhaps the only practical exception worth mentioning is the Muslim Sisterhood (al-akhawat al-muslimat) experience within the Muslim Brotherhood (al-ikhwan al-muslimun), which originally started outside the framework of the organization of the Brotherhood - a fact which was neglected by the Islamists themselves, and whose implications were understated. ${ }^{6}$

Lack of Revision and Self-Criticism: One notices the scarcity of Islamic writings that re-think the dominant theses in the Islamic arena in order to reform them, ${ }^{7}$ as well as the scarcity of critical writings from within the Islamic movement. ${ }^{8}$ Meanwhile, many important socio-economic issues that women face nowadays continue to be ignored and the clash with the secularists persists. If the secularists call for women's rights in labor markets, Islamists would have reservations; and if the secularists defend 
women's political rights, fatwas would be issued to discourage women from running in parliamentary elections or to restrict their political participation. These fatwas would also prohibit them from working as judges or in high profile positions and accuse the other party (the secularists) of conspiracy, treason, zionism, masonry, and of being tools of westernization. ${ }^{9}$

Neglect of the Legal Aspect: The focus on rights derived from Islamic Law (shari'a) is done in the framework of customs and local norms (al-'urf and al-fadl) without any attempt to make legally binding formulations or proposals as is the case in civil and criminal matters. Recent jurisprudential interpretations (ijtihadat fiqhiya) in the field of women's rights within the family remained in figh books without the Islamic groups ever pushing for their implementation. Indeed, most developments in personal status codes in the Islamic world were actually accomplished through initiatives by governments or legislative authorities under religious supervision and were not pushed for by Islamic groups. Rather, the latter often oppose publicly some of the reforms related to women's rights, even when these do not contradict the provisions of shari'a. This is what happened in the 1970s when the Islamists attacked what they call the "Jehan al-Sadat" law and what is currently happening in Arab countries with respect to complex issues such as simplifying divorce procedures, control of polygamy, restricting divorce procedures, etc. ${ }^{10}$

\section{Characteristics of the Secular Discourse on Women}

The Absence of ljtihad: While Islamists are accused by their opponents of being attached to traditional interpretations bound in time (salafyat al-zaman), secularists can well be accused of being salafi in their own way due to their attachment to place or space salafyat al-makan. The secularists/liberalists/ and leftists are often examples of the lack of any serious effort to practice ijtihad when dealing with or reviewing philosophical precepts and dogmas. They lack a sense of self-criticism despite affirming their cultural and national identity and indicating broadly that religion defends rights and freedoms. ${ }^{11}$

It is to be noted that in most Arabic studies on women, there is no real attempt to develop indicators that reflect the civilizational framework and the nature of political practices in Arab/Muslim societies. Instead, these studies adopt Western indicators to evaluate women's status in society, where institutionalization and paid labor are used as criteria. To measure women's political participation, the criteria used include the percentage of female voters among the women registered to vote, the percentage of women running for elections, and the percentage of women in political parties, parliament, and executive government positions. All these indicators are institutional and structure-oriented and overlook many levels related to women's non-institutional, informal, and silent political participation. They do not accurately reflect women's role in the political sphere, and might even be misleading if they are not interpreted in light of the crisis of legitimacy in the political regimes of nonindustrialized countries, and the role of society in comparison to the state within the Islamic cultural framework.

Non-Historicity: while the Islamic movement's discourse is accused of over rating the historic experience, the secularist discourse ignores the evolution of the "women's 
emancipation" movements under secularism into "feminist" movements and does not grasp in many instances the difference between the two. Feminism - in some of its factions - goes beyond demanding equality by seeking to highlight women's uniqueness (and sometimes even their superiority) and by separating them from men in their struggle and daily practices. Radical feminism for instance entirely rejects the family as a basic unit while accepting homosexuality. It is also a "femino-centric" movement. Furthermore, the secularists ignore the relativity of ethical issues in a global world and how this affects society and women. They do not try to figure out how their theses should lead to conclusions or solutions different from Western ones, or how to solve such issues as rape, sexual harassment, the collapse of family structures, and the financial and daily burdens undertaken by women in return for their demand for equality. ${ }^{12}$

The secular discourse does not honestly answer the following question: how can the development of the Arab women's movement avoid following the same course of Western women's liberation? What constitutes the specificity of the Arab women's liberation movement in light of its exclusion of religion as a frame of reference and only paying lip service to it while drawing heavily and uncritically on international human rights instruments instead of drawing on Islamic principles? How can the jurisprudential issue of the "constant" and the "changing" in legal matters be dealt with under secularism? ${ }^{13}$

Lack of Revision and Self-Criticism: The secular discourse in general does not try to engage with the other groups in a profound manner. Instead, it tends to oversimplify when dealing with important issues. Consequently, the "Islamic movement" becomes "an outmoded current opposing women and threatening their achievements"; the hijab is always "a symbol of oppression, irrationality, and patriarchy"; and Islamic theses and practices "marginalize women and threaten to confine them to their houses".14 This attitude not only simplifies a complex phenomenon, it also reflects ignorance of facts such as the high level of awareness and political involvement of women in the Islamic movement and in civil associations and unions. It also ignores the fact that more and more educated women are embracing the Islamic vision as a path to liberation.

Excessive Legalism: While the Islamic discourse and actions neglect to codify women's rights, secularists emphasize the importance of the law and ignore the role of norms (al-'urf and al-fadl) and social solidarity which cannot be overlooked when it comes to social issues (Hussein, 1993). The State and the law cannot fully replace norms and society which can often protect women's rights and solve conflicts much more than the laws related to marriage, for instance.

Breaking Away from Heritage and Tradition: The Arab secularist discourse speaks of heritage but it knows very little about it. It criticizes and often contradicts it. It does not make a distinction between heritage and shari'a. Indeed, this discourse appears to be totally ignorant with respect to fiqh, its theories, and Qur'anic jurisprudence. It asks for ijtihad and rationalization when it is not even capable of doing what it preaches. This is why the secularist discourse is losing battle with the Islamists on many issues as well as losing its popularity and credibility (e.g. the issue of changing the personal status codes in several countries). It is deprived of a major, 
rich source of knowledge that can enable it to develop new arguments and means for change in our society.

\section{The ljtihad of the Islamist Movements and the Rigidity of the Secularist Intellectual}

Islamic movements have long been accused of rigidity and ignorance by secularists. However, upon scrutiny, one realizes that the secular discourse has not developed its own assumptions and ideas in decades. This discourse still revolves around criticizing patriarchy which, from an Islamist perspective, is completely different from the concept of "men's guardianship over women"(qiwama).

"Patriarchy" etymologically means "rule of the father" and goes back to Greek and Roman ages when the male head of the family had absolute power over everyone under him: sons, daughters, daughters-in-law, etc. This kind of authority was only given to men who controlled the family's wealth and decided who their sons and daughters married without asking for their consent or even consulting them.

This image of the authoritative patriarch can be understood from the etymological meaning of the word family itself which, during the Roman empire, included the farm, the house, money, and slaves, or the inheritance that the father leaves to his heirs. Women were part of that inheritance.

The concept of patriarchy has been used in modern writings to criticize the father's control within the family. In the 17th century, Robert Filmer was the first to use the patriarchal family prototype to analyze systems of governance. Filmer found that authoritarian governments are those where the ruler treats his subjects like a man treats his wife and children. Locke criticized this analogy for being a pseudo-analysis of a political phenomenon though he did not mind the father's authority within the family. This concept was later commonly used in Marxist writings; it is also a pivotal concept in feminist critique of men, family, society, and the state.

The use of the concept of patriarchy in the West is linked to two major schools of thought: the liberal secularist one that believes that religion has been used to justify and legitimize patriarchy within the family, and Marxism which used the concept to criticize the hierarchy within society and the state, which were found to be permeated by patriarchal structures at all levels.

The difference between the Islamic vision and the Western vision of the family is due to the different stands on religion and the relationship between men and women, and the differing attitude towards the state and the nature of authority within it. It is an epistemological and political difference that cannot be grasped separately from the political theory behind each vision (Sharabi, 1992).

Furthermore, secular attempts to deal with canonical texts have been mostly based on interpretations that did not take into consideration the accepted classical methods related to Qur'anic exegesis and jurisprudence (figh), and included attacks against transmitters of Hadith by doubting their faithfulness and constraining the text's 
validity to the historical period it appeared in, in an attempt to label it as a historical text and to limit its relevance across time and space. Such examples include Fatima Mernissi in her book The Veil and the Male Elite and Farida Banani in her writings about the necessity to re-read Hadith. One notices here that religious texts are not dealt with in accordance with the principles of Islamic jurisprudence but by using an approach closer to discourse analysis and by drawing on contemporary Islamic writings on this issue without adopting these Islamist writers' evolved vision on other issues such as the call for the renewal of the principles of figh. Resorting to religious discourse only occurs when discussing women's issues while the background of these [female] researchers remains primarily a secularist one. ${ }^{15}$

Meanwhile, there have been important signs of renewal in the Islamists discourse on women. ${ }^{16}$ I will explore the thought of two contemporary scholars who have had great influence on the Islamic resurgence movements since the sixties of the twentieth century: Mohammad al-Ghazali and Yusuf al-Qaradawi. Both are examples of such contemporary voices for change, and are scholars who introduced religious opinions of reform and renewal, especially regarding women's issues.

\section{Al-Ghazali and Women's Grievances}

From the very start, Sheikh Mohammad al-Ghazali was concerned with advocating Islamic shari'a. Readers notice in his writings a dedication to defending Islam against colonialism, communism, and capitalism. ${ }^{17}$ He deconstructed nationalist thought and Arab Ba'thi ideas (al-Ghazali, 1977), criticized the thought of the orientalists (al-Ghazali, 1964) and attacked al-salibiyya (or the new crusades) and its supporters (al-Ghazali, 1975b).

The sheikh was indeed engaged, during the first phase of his life, in defending Islam. He fought famous intellectual and cultural battles in the fifties, sixties, and seventies of last century. He also took interest very early on in the problems that women face in the Muslim world. He did not ignore women; rather he devoted much time and attention to them. In his book al-islam wa-l-taqat al-mu'attalah (Islam and wasted potential) which he published in the beginning of the sixties, al-Ghazali noted that the situation of women in the Muslim world was dire and called for change, preaching a return to the fundamentals of religion. However, he kept repeating some precepts that reflected his traditional Azhari background: "the jobless woman is better than the corrupt woman, and women confined to the bedroom and the house, limited to serving their children and husbands, are more virtuous than those exposed for all to see and to touch" (al-Ghazali, 1983a, p.100). He went as far as arguing that men are stronger than women, and that the fact that a few women have excelled in the public sphere does not discredit the general rule that men are more capable than women, that men are the builders of civilizations, and that humanity would not be what it is today without men. He also believed that the women's movement is only the byproduct of a feeling of pain and guilt that incited some men to liberate women from the shackles that other men had tied them down with (al-Ghazali, 1983a).

Al-Ghazali mentioned in his writings women's role in the first Islamic societies as opposed to the present where they have become a negative force compared to that golden age in history. However, he was reserved in his call for change, fearing the prevalent Western model that, in his opinion, he was seeking to pull women out of their houses and involve them in the public sphere without any limits to such 
participation. Maintaining morality and preventing practices that might lead to sin (e.g. the jurisprudential concept of "eliminating pretexts" or sadd al-thara'i') were the main concerns that the reader observes in al-Ghazali's early writings. His maxim during that period, ("we do not want to have to choose between two evils") remained broad, lacked detail, and failed to provide any acceptable or alternative model (al-Ghazali, 1983a, pp. 113-122)

In his book Huquq al-insan bayna ta'alim al-islam wa i'lan al-umam al-muttahidah (Human rights: Between the teachings of Islam and the United Nations Declaration), alGhazali used the same approach. He called for women's participation but set conditions for this participation such as the need for money or restricted it to specific professions which are considered "more suitable for them". He also defended men's qiwama but did not deal with men's abusive behavior towards women (such as preventing women from being involved in the public sphere) (al-Ghazali, 1983b, pp. 115-139).

A few years later, al-Ghazali realized how important it was to look at the bigger picture, to develop arguments and ideas, and to focus on the ultimate aims of Islamic law (makassed al-shari'a) to understand the importance of women's role in the nation. Soon later, he realized that focusing on the limitations rather than the importance of women's role and participation was an inversion of priorities:

Depriving women from education and worship in the personal, social, and political realms cannot possibly please God and his Prophet. Muslim women were not treated that way during the Prophet's days, or during the time of the Caliphates or other prosperous times... We should study the book of God; the tradition of his Prophet (Sunna); the figh of the Prophet's companions, their followers, and the famous imams in order to draw our faith from the right sources (al-Ghazali, 1994, pp. 335-337).

In the seventies, al-Ghazali engaged in the struggle to amend the family laws on matters that he believed went against God's law, like polygamy and divorce. It was a struggle he engaged into to protect the unity of the family and of society, and which kept him from dealing with other issues related to women (al-Ghazali, 1991a). In the eighties, he started developing his thoughts and ideas on women in a larger context, scrutinizing traditions and developing a sound methodology to deal with the fundamental texts of Islam (Qur'an and Sunna) and dispel any misreading of these texts that can be affected by personal whim or inherited customs and traditions.

In his book Dustur al-wehda al-thaqafiya bayna al-muslimin (the constitution for Muslim cultural unity), al-Ghazali called for a return to the "pure origins" in order for Muslims to unite, regardless of their ideological and cultural differences with regards to various issues, including women's issues:

When looking into the social status of women, I have noticed that whenever two sayings by the Prophet deal with the same issue, the weaker Hadith is always preferred to the correct Hadith.

There are a few weak ahadith [plural of Hadith] out there that control Muslim societies and supersede not only correct ahadith but firmly established ahadith 
as well... and dealing this way with prophetic Sunna cannot be a sign of a proper religion or of a straight path. (al-Ghazali, 1981, pp. 29-31)

He also blamed in general those involved in religious lawmaking for their incompetence and inexperience, as they are not well-versed in Qur'anic jurisprudence. As he maintained:

Some religious scholars still hate the woman and blame her for Adam's exile from heaven, the way Jews claimed in their books. They believe in confining women to their homes until their death and stopping them from participating in the public sphere. I believe if those scholars lived in the time of the Prophet (PBUH), they would have asked him to chase away the two women who attended the grand allegiance to Islam ceremony in al-'aqaba al-kubra. They would have told him women have nothing to do with these things. If they were present during the conquest of Mecca, these scholars would have told the Prophet to obtain men's allegiance only and then these men would teach their women [to give their allegiance to the Prophet] (al-Ghazali, 1981, p. 179).

Al-Ghazali went to the root of the problem and realized, after having been busy with the Islamic call (da'wah) for a long time, that Islam has many enemies on the inside and that they lack understanding and perspective. He understood that Muslims, more than the enemies of Islam, are to blame for the problems that have plagued Islam in modern times as well as in the past (al-Ghazali, 1984b).

The sheikh's later writings showed how his interaction with women in fatwa councils and in universities influenced the way he perceived women's issues. These writings reflected a shift from history and tradition to contemporary issues affecting women in Islamic societies. This is clear in the examples he used and the facts he presented based on lived experience in a society where there is a rift between the teachings of Islam and the status of women. In his book Ma'at su'al'an al-islam (A hundred questions about Islam), he asked: "First, have women in the Islamic world been treated according to the teachings of Islam? I believe this has rarely been the case" (alGhazali, 1984a, p. 253).

The sheikh proceeded to answer questions on women's issues and roles and emphasized the importance of their education and participation in mosque activities. He also highlighted the fact that women should follow the example of the Prophet's wives and female companions in faith, work, and jihad, and he explained women's rights in society and within the family.

The sheikh knew that people of "corrupted religiosity", as he labelled them, those whose motto is "by God, we will stop the women", and who have historically opposed the emancipation of Muslim women since the era of early Islam ('asr al-rissalah) (alGhazali, 1985), will claim that his ideas are Western and compatible with modernity. He responded to these claims by saying:

I do not want to be seen as a proponent of Western civilization in our society, for the West has both good and bad traditions. What I do want is to activate both 
written texts and those derived from the biography of the Prophet (PBUH) and that of his first predecessors (al-Ghazali, 1984a, p. 257).

It was a matter of going back to the prophetic Sunna, of thoroughly understanding the Qur'an, and of coming up with figh that is discerning with respect to social conventions. He even went as far as saying that the future of Islam required a new perspective on many issues, with women's issues being one of them. He added that restrictive attitudes with respect to women allowed enemies of the faith to manipulate Islamic societies: It is fair to say that the unjustified criticism by Christian missionary leaders against us did not come out of nowhere. The life stories of some Muslims and the fatwas of some pseudo-experts in fiqh represent a great scourge to Islam" (alGhazali, 1991b, p. 130).

By the end of the eighties, al-Ghazali published his important book Al-sunnah alnabawiya bayna ahl al-figh wa ahl al-Hadith (i.e. the Sunna between scholars of figh and the scholars of Hadith) in which he compiled his thoughts and observations on various issues related to tradition and cultural heritage and his reading of some texts from Hadith and the Prophet's biography (sirah) as well as women's issues.

In the second chapter entirely dedicated to women and the issue of hijab, he deemed it acceptable for women to expose their face. He did not believe this to be going against the community of scholars. He gathered evidence to prove that his view on this issue which is the source of much controversy - agreed with that of the four most important Islamic schools of jursiprudence. Thus, he started with the issue that was often used as a pretext to completely shut off women from the public sphere. His goal was to return to the roots of Islam and to revive a moderate strand in Islamic jurisprudence which has been largely suppressed (al-Ghazali, 1989).

The sheikh moved on to look into issues related to women, the family, and public jobs. When he called for Muslim women's participation in public life, he argued convincingly that virtuous Muslim women are capable of playing a major role in developing the nation and can, just like men, be entrusted with preserving religion. While the sheikh was concerned with women's role inside the home during the sixties, in the eighties he seemed more aware of women's situation and the role that the first female companions of the Prophet paved the way for. He was trying to find a balance between women's duties within the family and their duties towards the nation. In the early sixties he wrote:

I have been known not to encourage women's work anywhere, nor to equate them with men in all fields. I have said that the role most suitable for a woman is that of a housewife. However, some jobs are better done by women, and some young women might need to work before they marry. Furthermore, financial situations have a huge impact on the way different people understand matters of daily life. And I do not like spreading partial [or incomplete] legal responses [or fatwas] in the absence of a larger Islamic context in our busy world (al-Ghazali, 1994, p. 399).

We see that al-Ghazali has realized that nowadays the nation needs women who step out into the public sphere now that the enemy has invaded the Muslim world in the 
realms of politics, economy, media, and education. He therefore refined his earlier restrictive opinions and asserted in his book Al-sunna al-nabawiya bayna ahl al-fiqh wa ahl al-Hadith the importance of family while also emphasizing women's role in the public sphere:

Women can work both inside the house and outside it. However some guarantees are required to preserve the future of the family. It is also important to provide an environment of piety and chastity in which women can work. It is important in Muslim societies to abide by the ethics of shari'a and the limits set by God ... I know of virtuous mothers who are principles in renowned schools, and I know of brilliant women doctors who have honored their families and their jobs. And correct piety was behind it all (al-Ghazali, 1989, pp. 52-53).

Based on this increasing trust in Muslim women's competence and in their contribution to the advancement of their community while also caring for their family and homes, the sheikh acknowledged that some women are good at managing the affairs of the community on different levels. He added that it is best when a competent person is given a position of responsibility, be it a man or a woman, and wrote: "What do masculinity and femininity have to do with anything here? A pious woman is better than a blasphemous bearded man" (al-Ghazali, 1989, p. 59).

Al-Ghazali focused on the Muslim nation and its women in his book on women and traditions (Qadaya al-mar'a bayna al-taqalid al-rakida wa-I-wafida), published in the early nineties. He wrote in the Introduction that humanity flies with the wings of both men and women and that if either of the wings were broken, humanity would come to a halt and crash. He said that the ills of Islam lay in what was said about it, not in the ahadith themselves (al-Ghazali, 1990b).

The sheikh moved from one issue to another in his book, starting with key concepts related to the role of women, comparing their role in Islam and in other societies, and deploring their current condition (al-Ghazali, 1990b). Al-Ghazali cited historic instances of women's (forgotten) participation and contribution in the rise of Islam as a civilization, under the titles "One Woman is Worth a Thousand Men" and "Women in Science and Literature". In the third chapter, he spoke of women's role within the family under such titles as "Do not underestimate the Duties of a Housewife" and "Homes are Built with Love". In the fourth chapter, he dealt with misconceptions that needed to be corrected such as qiwama, the dowry (mahr), house obedience (bayt al-ta'a), restrictions in applying for divorce, and women's participation in mosques. He reminded men and women of the standards of good behavior and propriety in a virtuous Islamic society. Al-Ghazali shared his knowledge in numerous universities such as Al-Azhar, Umm Al-Qura, and the University of Prince Abdul Qadir in Algeria, often criticizing the understanding of women's role by young people who are active in Islamic revivalism (al-Ghazali, 1990b).

The epitome of the sheikh's writings was probably what he said in his following book, Turathuna al-fikri fi mizan al-shar' wa-I-'aql. In this book he further honored women by documenting their contribution to "Islamic civilization and its heritage" and preserving the faith, and emphasized how women contributed to the religious, cultural, 
and social developments during different phases of Islam (al-Ghazali, 1991c). In his last publications, the sheikh consistently included women in his discourse on Islam on various issues, thus asserting after a long intellectual journey that the development of the nation was achieved and continues to be so by both men and women.

Women and the Family

While al-Ghazali's experience helped polish his vision on the need to care about women's issues in our Islamic world and to use a sound moderate Islamic perspective for that purpose, what was clear in his writing from the start was his early realization that the family unit was central to the Islamic worldview and an essential element in the fight against the threats this worldview is facing nowadays.

This interest had an ethical moral dimension in the beginning, when the sheikh started attacking vices that resulted from women's unveiling and engagement in the public sphere and the subsequent calamities that afflicted family life (al-Ghazali, 1983a). When al-Ghazali wrote on human rights, he dedicated part of his work to the family, thus pitting the Islamic concept of rights in its collective or group form against the individualistic secularist concept and affirming that the family is the starting point for rights and duties and is the building block of society. It is a vision that contains the essence of the theoretical Islamic model (al-Ghazali, 1983b).

His writings constantly defended women's rights but warned against the sins committed as a result of including them in the public sphere, emphasizing the importance of abiding by Islamic morals and not straying from them one bit, otherwise corruption would prevail (al-Ghazali, 1983a). He expressed this thought eloquently when he wrote: "We do not want women to go from a state of women living in 'closed quarters' (harim) to a state of haram (vice)" (al-Ghazali, 1994, p.338). He explained that a middle ground was the solution, i.e. neither following in the footsteps of the West nor abiding by the status quo:

The family is the basis of society, and anything that threatens its existence, weakens its authority, or corrupts its nature should be prohibited in the name of Islam. Everyone has come to know that Islam is a holistic system, and adopting some of its teachings while ignoring others does not create an Islamic society. Issuing fatwas based on partial truths or facts could negatively impact Islam, the nation, or both (al-Ghazali, 1994, p. 339).

Al-Ghazali also asserted women's rights within the family, maintaining that women have the right to initiate and get a divorce (khul') based on shari'a. He thus not only defended Muslim women, but also God's law and the cohesion of Muslim society: "The laws of Islam are not personal cases that only concern some people who believe they can keep these laws or change them if they wish to" (al-Ghazali, 1991a, p. 204).

The sheikh spoke in mosques during Friday sermons, preaching to Muslims the importance of defining roles within the family in accordance with God's law (shar'). He did not only address the "gentlemen" who wanted to change state laws, but also urged people to hold on to God's law in their daily practices inside the family and in secular laws (Abdelhameed, 1988). Thus, he reminded the nation of the commandments 
of the Prophet in his farewell speech, where he urged his followers to be kind to women (Abdelhameed, 1988). On another front, he attacked the unorthodox ways that have permeated the relations between the two sexes and the family and called for an awakening among Muslim men and women alike (al-Ghazali, 1983c; al-Ghazali, 1987b).

When people complained to the sheikh, he realized the extent of the injustice that prevailed in divorce cases and how many men abused their prerogative (to divorce their wives). He expressed compassion towards the women who complained to him by enumerating their rights (al-Ghazali, 1984a), and saw the solution to this problem in educating people rather than introducing new laws to constrain divorce which shakes the foundations of the Muslim home (al-Ghazali, 1990a).

The sheikh adopted a stance that both reinforced women's participation in the affairs of the nation and emphasized the importance of the family and of women's role within it. He realized that sayings and good intentions do not solve the problem, and sought a solution that could achieve this balance. One of his ideas was to provide women with part-time jobs so that they could get the best of both worlds: the family sphere and the public sphere (al-Ghazali, 1984a).

He called for re-examining "how relationships between the two sexes in early Islam were regulated, how family members were able to gather in the court of the mosque ... and how all scholars concurred that whenever the Islamic nation was under attack, every Muslim man and woman had to answer the call of duty by sacrificing their selves or wealth" (al-Ghazali, 1983c. p. 232). In light of these relationships that are predetermined by God's law, one can imagine the healthy environment in which a family can thrive, prosper, and accomplish its mission (al-Ghazali, 1983c).

Towards a Well Guided Women's Renaissance

Many voices have, since the beginning of the century, warned against calls for promoting women's liberation made under the umbrella of secular human rights. Many Islamists went so far as to accuse the secular movement of treason and decadence among other things, but Sheikh Mohammad al-Ghazali blamed the Muslims. He called for the exercise of self-criticism, asserting that "the cultural invasion was spreading because of the void Muslims suffer within" (al-Ghazali, 1987a). The sheikh advised the proponents of women's liberation to ground their movement in Islam if they want it to succeed (al-Ghazali,1983a).

He added that "a well guided women's renaissance requires that a certain type of proponents of women's rights be ignored; they are the slaves of Europe and want to instill decadence into our nation. They care neither about virtue nor about the family. They are blind followers" (Abdelhameed, 1988, pp. 159-160).

The sheikh's experience in Algeria made him even more aware of the dangerous polarization between a group that wanted to marginalize women and another that wanted to marginalize Islam (al-Ghazali, 1991c).

In his book qadaya al-mar'a (women's issues), he expresses these concerns again and shares his fear that "if religious leaders took over power, women would be locked 
behind closed doors and their faces would never be seen" (al-Ghazali, 1990b, pp. 3031). Hence, a sound Muslim women's renaissance led by educated working women is what is needed. According to the sheikh, it can set things straight and cure the nation with the healing power of Islam, not with Western remedies that only make things worse.

\section{Women in the Thought and Fatwas of Sheikh al-Qaradawi}

Al-Qaradawi has dealt with issues related to the modern Muslim woman and defined how the Islamic vision perceives her role as a human being, female, and member of the Islamic society. He acknowledged how some have reduced all three levels to one level only: the level of femininity. Women were only seen as a source of seduction and a means for procreation. Ignored was Islam's assertion of woman's humanity, her legal abilities (taklif), and her equality with man with respect to the origin of creation, general human properties, responsibilities, judgment, and destiny. This is an equality based on monotheism (tawhid) and devotion to God ('ubudiyya); an equality under which the difference between masculinity (thoukoura) and femininity (ounoutha) is one of complementarity in order to ensure that both sexes can act as vicegerents (khilafa), without hindering women from being able to perform and achieve. He added that the difference in treatment with respect to witnessing in court (shahada), inheritance ('irth), and men's guardianship over women (qiwama) exists only to make mutual guardianship in faith (wilaya) in the relationship between the two sexes possible in Islamic society. These differences do not contradict the general principle of equality between men and women in legal injunctions (al-Qaradawi, 1977); "this discrimination is determined by the innate natural difference between men and women".

According to al-Qaradawi, Islam respects women's femininity and tries to preserve it within a framework of general moral codes and legal provisions, in order to organize women's activities in society rather than restrain and limit them. Islam tries to protect women from confusion and uncertainty rather than to stop them from participating and being active individuals. The sheikh reaffirmed this in his writings where he invoked correct ahadith and events from the biography of the Prophet (sira). These show how women contributed during the times of the Prophet in spreading the message in mosques and in assemblies of learned people (majlis al-ilm) and were involved in public events as well as in defending religion and the state through jihad in the name of God (al-Qaradawi, 1993b).

Through their role as human beings, mothers, wives, daughters, and active members of the Muslim community, women's identity is forged and developed the way it is formulated in Qur'anic verses and the Prophet's ahadith and the way it was implemented by the Prophet's wives and female companions. The sheikh elaborately explained this evidence by following Islamic legal canons and considering the ultimate aims of Islamic law (makassed el-shari'a). He gave a lot of weight to the woman's role within the family which he considered to be the first social unit in the structure of the Islamic umma. He saw the family as a priority and the center around which everything else revolved, and thus adopted a middle ground between a group that wanted to control women and their activities on the one hand, and a group that was guided by the West and wanted women to follow in the footsteps of Western women without any consideration for the consequences, on the other hand (al-Qaradawi, 1993b). 
Islam's Legal "Middle Way" and Women's Issues

Al-Qaradawi calls for a methodological "middle way" (manhajyya wasatyya) by condemning two perspectives on women:

There are those who do not do women justice and look at them condescendingly and consider them Satan's agent of seduction and decadence, deficient in intellect and in the observance of religion (naqissat 'aql wa-din) ... In opposition to those who undermine women and wish to oppress them, are those who have overglorified women and have crossed the boundaries set by God, by nature, and by virtue. While the former are slaves to inherited Eastern traditions, the latter are slaves to imported Western traditions (al-Qaradawi, 1993b, pp. 382-393).

The sheikh looks for the root of the extremists' restrictive views about women in Islam and finds it in their methodology, dealing with the fundamentals of religion, and legal injunctions:

They either ignore a correct text in the Qur'an or the Sunna, or they disregard facts that have been mentioned in the biography (Sira), while using ahadith like "women are deficient in their reasoning and observance of religion" (naqissat 'aql wa-din). They even use weakly transmitted ahadith of ill-known sources to hinder women and deprive them of their rights. They try to make women's life a dark prison (alQaradawi, 1990, pp. 9-14).

In his views, there are two reasons behind this restrictive standpoint. Firstly, the majority are ignorant of religious texts whose purpose is to ease life (tayssir) and resist complications (ta'ssir), especially texts in the prophetic traditions that have been established to be true. Secondly, they misunderstand the texts by applying them in the wrong context or drawing incorrect legal rulings from them. They even truncate these texts, omit the contexts they were mentioned in, or isolate them from other rules of Islam and its holistic purposes instead of conciliating them with other texts (alQaradawi, 1990, pp. 10-12).

\section{Women: Legal Competence and Guardianship}

Al-Qaradawi did not only detect this problem of imbalance and comment on it. He also tried to restore balance through his numerous fatwas. This is concretized in his writings on two issues: the first is the interpretation of the Hadith "O women, I have not seen any one more deficient in terms of their reasoning and observance of religion (naqissat 'aql wa-din) than you. A cautious, sensible man could be led astray by you". Some used this Hadith as an excuse to treat women as lesser individuals and deny them their rights which the shari'a grants them. The second issue is related to his fatwa about women running in parliamentary elections.

The sheikh criticized those who considered the above mentioned Hadith, alone, to be the main text when dealing with women in Islam. He considered this approach to be a gross methodological mistake on their part because it goes against accepted methods of dealing with the Qur'an and the Sunna regarding various issues (al-Qaradawi, 1990). Furthermore, the sheikh emphasized the fundamental rule for studying a text which must be understood in light of its context, i.e. the occasion and reason for sending it 
down to the Prophet (asbab al-nouzoul). Only when this is done, can one look into the universality or specificity of these texts (al-Qaradawi, 1992a).

He explained the occasion for sending down this Hadith which was attributed to Abu Sa'id Al-Khudri and reported by Bukhari and Muslim. The prophetic saying about women reveals their faulty memory concerning matters of life and weakness of religion due to the necessity of avoiding some acts of worship during menstruation:

It is clear that the Hadith does not set a general rule. Rather it expresses the Prophet's (PBUH) surprise at a paradoxical situation where women who have some weaknesses have been able to overpower determined and resolute men (alQaradawi, 1992a, p.199).

The sheikh looked at the context and occasion of the text and noted:

The text needs to be studied and contemplated from various angles: the occasion on which it was said, who it was addressed to, and based on the way it was formulated. Only then can we understand the way it perceives women. As for the occasion on which the speech was said, the Prophet was delivering a sermon on a Muslim celebration day. It is hard to believe that the Prophet, a man of great morals, would inconvenience women as such, degrade them, or undermine them on such a joyful occasion. Concerning the audience of this speech, they were mostly women from the city of Medina - mostly supporters of the Prophet (al-ansar) about whom Umar bin al-Khattab said: "when we came to the city, we saw men overpowered by their women, and so our women started to adopt the behavior of al-ansar." And this is where the saying "naqissat 'aql wa-din" came from. It was mentioned just once to attract the attention and as a soft introduction in a sermon addressed to women, and not as an independent and factual statement before either a female or male audience (al-Qaradawi, 1992a, p.199).

As for women's candidacy in parliamentary elections, the sheikh started his fatwa on the issue by setting the general framework of women's participation in society and allowing it as a basic rule. Then he tackled the details of the issue slowly and meticulously with respect to spoken, practiced, and normative tradition and Sunna. He also dealt with the legal concept of sadd al-thara'i' (lit. eliminating excuses or pretexts):

There is no doubt that sadd al-thara'i' (i.e. eliminating pretexts) is needed. However, scholars have decided that going overboard with this rule is just as bad as accepting it. Sadd al-thara'i' can lead to many losses that are more significant than the feared potential corruption.

There are some who infer that women running for parliamentary elections are trying to rule men, which is prohibited. The Holy Qur'an even stated that men have guardianship (qiwama) over women. Hence, how could we invert roles and give women qiwama over men?

I would like to highlight two points here: the first one is that the number of women who run for parliamentary elections is minimal, and so the majority in parliament 
will continue to consist of men. And this majority holds the power ... The second point is that the Qur'anic ordinance, when speaking of men's qiwama over women, meant it only within the marriage context ... As for women's qiwama over men outside the family, nothing was mentioned to prohibit it. What is prohibited instead is the public governance or rule by women over men.

The Hadith reported by Al-Bukhari, according to which the Prophet said "a people will not succeed if they entrust their affairs to a woman" referred to public rule by a woman over a nation as president of the state, as the word "their affairs" indicates. On a few matters or affairs, there is no objection to the rule of women (wilaya) such as rule with respect to issuing fatwas, exerting effort in Islamic jurisprudence (ijtihad), education (ta'lim), transmitting prophetic Hadith (riwaya), or administrative work (al-idara). These are fields where women have the right to wilaya by consensus (ijma') and in which they have been active throughout the centuries (al-Qaradawi, 1990, pp. 24-25).

The Muslim Woman of the Future and the Islamic Movement Sheikh Yusuf al-Qaradawi adopted the rulings of Islamic Law (hukum al-shar') in order to understand the issues related to Muslim women, and his writings and fatwas came to exemplify a moderate Islamic vision. However, the sheikh also realized that women's issues are not only a matter of Islamic jurisprudence and rulings, but also a matter of action and work. Al-Qaradawi beleived in the role of Muslim women in building the future of the nation so that the latter would reclaim its glory and its leadership. He knew that restoring past glory would only happen by going back to the fundamentals of religion and using as example the Prophet's biography (Sira) and the life of his female companions. In his opinion, these are the correct examples to follow, instead of emulating periods in the past when women were forbidden from being part of society and isolated from both religious and worldly matters, i.e. they were not allowed to go to the mosque, to contribute to society, or even choose their lives as wives and mothers:

We do not wish to go back to a time of backwardness and decadence. We want the Muslim woman of the future to model herself after the first Muslim woman who lived in the time of the Prophet, his Companions and their followers, as well as in the golden age of Islam during which the woman fulfilled her duties and knew her rights fully (al-Qaradawi, 1993a, pp. 372-381).

By saying so, the sheikh was actually calling for a new awakening for the Muslim woman that goes beyond Western slogans of liberation and reaches back to the roots (al-Qaradawi, 1992c). The Muslim woman consequently bears the responsibility of acquiring knowledge and holding on to her Islamic rights and duties. Only then can she fully understand her role, fulfill the trust God placed in human beings (amana) and proclaim Islam as the religion of God (al-shahada), the way the Prophet's female companions did. This is why the sheikh invites women to understand and live according to the Prophetic message:

This is what I want of the Muslim woman of the future. I want her to be Muslim, to know about her religion and life, to fulfill her duty towards God, towards her husband and children, towards her society, religion, and Islamic nation. We 
want the Muslim woman to lead a real Islamic renaissance. We want her to be the Muslim educator and guide who could teach other women and lead a real renaissance (al-Qaradawi, 1992c, pp. 29-32).

This Islamic revival, based on a strong commitment to the teachings of the Qur'an and the Sunna, was the awaited context needed to activate women's participation in public life. However, throughout his involvement in preaching and activism, the sheikh recognized and condemned the fact that women's work in the sphere of Islamic call (da'wa) has not reached the desired level. In his views, the Islamic movement has not given rise to women leaders capable (on their own) of facing the secularist and Marxist movements with adequacy and competence. The reason for this, in his opinion, is that men have been trying to control women and give them directions and have not given them the opportunity to express themselves freely (al-Qaradawi, 1991).

Due to his knowledge of people's nature and his mingling with different groups of people in numerous countries, the sheikh holds some women in high esteem and asserts that women's leadership is not impossible or unusual:

Among our sisters are geniuses just like men. Genius is not an exclusively male attribute. It is not a coincidence that we find in the Qur'an the story of a woman who led men with wisdom and courage and brought prosperity to her people. That was the Queen of Sheba mentioned in the Sura of the Bee (an-nahl) in her story with Solomon (PBUH).

I would like to say here very candidly: Islamic work has been infiltrated with extremist thoughts that have come to rule the relationship between men and women and have adopted the most restrictive views in this respect (al-Qaradawi, 1991, p. 71).

Al-Qaradawi took part in various Islamic conferences in the United States, Europe and Arab countries, and noted the severe segregation between the sexes. He saw that Muslim sisters were not allowed into many important lectures, discussions, and seminars that were held for men. He condemned this segregation on more than one occasion by calling the sisters to:

not give in to this situation and to take matters into their own hands by exploring, preaching, and opposing the voices of Western feminism that are infiltrating the beliefs and values of the nation. These voices may be loud but represent an oppressed few that have no weight, whether in religion or in life (al-Qaradawi, 1991, p. 73).

When the sheikh calls for women's participation, he observes how the West has been dealing with women and how the dominance of materialism and relativism has caused the collapse of social structures, and exposed women to injustice, oppression, rape, and sexual harassment, in addition to the dissolution of the family as a social unit. He is aware of the new Western social movements (such as calls in support of homosexuality) that can threaten our societies if we do not hold on to the unbreakable tie [of religion] (al-'urwa al-wuthqa). He warned against excesses that would lead to 
social dissolution if women's work and movement went beyond the code of conduct and limitations set by Islamic Law (shar'). He also warned against the other extreme based on the alternative principle of "eliminating pretexts" or sadd al-thara'i', which confines women to their homes and weakens their social participation (al-Qaradawi, 1995).

The responsibility lies on the modern Muslim woman, as the sheikh sees it, to be positive and liberate herself from outdated traditions that have been inherited and have weakened women's prominent role in the da'wa movement (calls to join Islam). Muslim women are required to adopt serious stances vis-à-vis contemporary issues and events, and to have the responsibility of changing and mobilizing other women around them and in their families within the general framework of the Islamic movement (alQaradawi, 1992b).

\section{V-Towards the Resolution of Conflicts: Between the Family and the Community}

While the ijtihad of some scholars, as explained above, tackled women's issues and attempted to emancipate women, it is to be criticized for having accepted the separation of private and public life while trying to conciliate them and prove that the two do not conflict. However, it is clear that ijtihad on women's issues in the future should adopt as its basis the fact that these two spheres are tightly intertwined and overlapping in Islamic vision.

Polarization as we have previously mentioned is a main element of the controversy around women issues in Islam and this is mainly noticeable with respect to the family: it is an essential sphere to be dealt with since one cannot discuss women's rights, participation, and condition without discussing the family. The family remains a controversial topic on both sides of the debate.

The Islamic discourse, in general, speaks profusely about women's role in the private sphere. The family is a field of regulations and moral constraints. It is the unit responsible for ensuring filial continuity and socialization. Even the ideas of the Islamic movement that highlight the importance of raising generations in light of Islamic values tackle these issues with an educational framework that excludes the political. In general, the Islamic discourse adopts the gendered division of labor; women are responsible for the private life of the family while men work for a living, uphold shari'a and build the state (socially, economically, and politically). Women rarely participate in the public sphere and when they do, their participation is restricted to education, missionary work and activity, medicine, and the like.

By contrast, the secularist discourse takes an opposing stance by considering women's work outside their home as a necessary condition for their financial independence, their self-awareness, and a guarantee of their participation in society. The family is considered to be the site where patriarchy is consecrated and where men oppress women. Motherhood is a biological function that is used to limit women's role to sex and child-rearing, while men monopolize culture and politics. The morals associated with women such as virtue and the glorification of motherhood are values that are meant to create false consciousness among women. Hence, women are pushed to 
participate in the public sphere to obtain their freedom and to improve their condition. This is the essence of the secularist discourse on women; the public sphere is a site of a professional nature such as being part of the labor force and getting wages, or of a political nature such as elections, political parties, and occupying high profile positions. What is distinct about this approach is the prioritization of the public over the private; instead of emphasizing the importance of the family and supporting women's position inside it, the battle was shifted to the public space while the private space was left to collapse or at least start to show cracks. One can also notice that even in the West, secularist feminists have started to reduce their attacks on the family and have started to realize the importance of reforming this institution "from within" instead of dismantling it. Meanwhile, the Arab feminist discourse still viciously attacks the institution of the family.

Undoubtedly, there is a need to break the dichotomy of the "private" and the "public" with respect to the debate on women's rights, their work, and their participation. The family should be rehabilitated as a social unit and then politicized in order to open it up to social issues, in order for women and mothers to participate in these social issues because they affect their familial, social, and professional status, as well as the future of their children and the work conditions of their husbands. This would make a new and effective basis for the mobilization of average women who are not attracted by slogans of liberation that do not make them feel politically committed. This would be a call for complementarity between the "private" and the "public" so that the two can interact.

It is also important to correct the false consciousness or view that women working in the public sphere should be exempted from their duties inside the home. If the assertion of women's role within the family goes hand in hand with their role in society (professionally, culturally, and politically), then we can guarantee an effective merging of women's issues that goes beyond slogans and can benefit the nation and women like any other grand national cause. The importance of women's role within the family as a fundamental social unit should be accompanied by a discussion on the importance of men's roles and duties within the family. Only then can men and women be both involved in the public and private spheres, without any of them exercising monopoly in either one of the two spheres.

Perhaps one of the keys of ijtihad to be applied in the future should be bridging the gap between social and Islamic legal sciences ('ulum ijtima'iyya wa-'ulum shari'iyya) since both al-Ghazali's and al-Qaradawi's attempts did not link the results of field research with figh and fatwa, which has become necessary. There should also be a comparativecontrastive analysis between the Islamic and the secularist/feminist theses.

One of the suggested solutions could be linking the concepts of vice-regency on earth (istikhlaf), public rule (wilaya), and competence (ahliyya) in the Islamic vision on the one hand with the concept of qiwama on the other hand, in order to associate it with the public sphere and not restrict it to the husband's duties inside the home. Qiwama is a concept in the Qur'an used repeatedly to express both sexes' duty in spreading the message of Islam. However, it has been reduced to a right exclusive to men within the family. 
This sort of quantum leap requires the participation of women who should turn to scholars and voice their problems and take them out of the personal sphere into the public realm, where ijtihad is exercised and fatwas are issued. Women researchers, lawyers, and scholars should take part in ijtihad in general in their own field of expertise while paying special attention to family and women's issues.

Pragmatic practical issues have separated Islamists and secularists. Rereading history and reinterpreting it could be a way for both sides to reconcile. The history of Islam was never against women, which should be easy for secularist women to realize when rereading history. Furthermore, rereading the modern history of the women's liberation movement since its beginnings, i.e. the end of the nineteenth century and the beginning of the twentieth, proves that Islam was a pivotal starting point for the movement's female pioneers. ${ }^{20}$ One also finds areas of interactions between some Islamists and secularists regarding women's issues that should be highlighted, instead of constantly focusing on differences and conflict.

The contemporary Arab-Islamic world needs a new and refined Islamic discourse for the liberation of women. This discourse should not attack Islam, marginalize it, or question its roots as proponents of women's liberation have done. It should draw on lessons equally from the Islamic and Western histories. This requires a collective ijtihad in a time when issues are so intertwined and complex that they cannot be dealt with by single individuals. This ijtihad should be the collective responsibility of a nation and will be key for a new awakening (nahda) and an opportunity for national reconciliation and change. Without such ijtihad, the Arab-Islamic nation shall remain hostage to this polarization and victim of a vicious binary opposition.

Translated by Dima Dabbous \& Farah Sahyouny

Heba Raouf Ezzat is assistant professor of political science and deputy director of the Centre for Humanities and Interdisciplinary Studies at Cairo University, and adjunct professor at the American University in Cairo. Email: heba.raouf2@gmail.com

ENDNOTES

\footnotetext{
* This article first appeared in Arabic, under the title "Al-mar'a wa-l ijtihad: Nahwa khitab islami jadid" in Alif: Al-Junussa wa-I ma'rifa: Siyghat al-ma'arif bayna al-ta'nith wa-I tadhkir, American University of Cairo, Journal of Comparative Poetics 19, 96-117.

1. In Islamic jurisprudence, it is the use of reason in the elaboration and explanation of shari'a or religious law. 2. It is to be noted that efforts towards Islamic/nationalist convergence is still in the works and there is still no consensus on any issue.

3. On academic discourse: See Jamal Mohammed Faqi Rasul al-Bajuri, Al-mar'a fi-I fikr al-islami, Masters Thesis, Al-Mosul University, Shari'a Department, 1987. Also see Ramadan Hafez Abd al-Wahab, Mawqif al-shari'a min al-mar'a fi-I wilayat wal mu'amalat al-islamiyya, Doctoral Thesis al-Azhar University, Faculty of Shari'a and Law, 1973.

4. See Samia Abd Al-Aziz Ismail Mnessi, Al-Sahabiyat wa-dawrahunna fi bina' ummat al-islam fi 'ahd al-rassul, Masters Thesis, (Cairo University, Literature Department, 1987).

5. See Mahmud al-Johari, Al-Ukht al-muslima assas al-mujtama' al-fadil. Cairo: Dar al-Akhbar, 1987; Mustafa al-Sibai, Al-mar冈 a bayna al-fiqh wal-qanun, (Beirut: al-Maktab al-Islami, 6th edition, 1984).

6. See Zainab al-Ghazali, Ayyam fi hayati (Cairo: Dar Al-Shuruq, 1984); Mahmud al-Johari, Al-akhawat al-muslimat wa bina' al-usra al-qur \aniya. (Cairo: Dar al-Wafa, 2nd edition, 1989).

7. One exception is Yusuf al-Qaradawi, Fatawi mu'assira, Part 2. (Cairo: Dar al-Wafa, 1993).

8. See Mohja Kahf, Al-musharakah al-siyassia lil mar'a fi al-haraka l-islamiyya" in Ahmad Bin Yusuf (Editor) Mustaqbal al-
} 
'amal al-islami: Al-haraka al-islamiyya fi thill al-tahawulat al-dawliya wa-azmat al-khalij (Chicago: United Foundation for Studies and Research, 1991), pp 87-97.

9. See al-Azhar fatwa on women involved in politics: Rissalat al-islam Journal, 4th year, Issue 3 (July 1952) and the complete fatwa text in Kamel Abboud Mussa, al-Huquq al-ma'nawiyah li-l-mar冈a fi-l-tashri' al-islami, Doctoral Thesis, AlAzhar University, Faculty of Shari'a and Law, 1982, p.156. We notice a change in the general direction of Al-Azhar as well as the direction of several movements (such as al-Ikhwan Al-Muslimin) after the Cairo Conference on Population and the Beijing Conference towards a more tolerant approach towards women's participation in politics and more explicitness in expressing this tolerance.

10. See Mohamad Siraj "Manhaj al-tajdid al-tashri'i fi-l-ahwal al-shakhsiyah fi misr fi al-qarn al-akhir" in Dirassat 'arabiya wa islamiya (Cairo: American University of Cairo Press, 1997), pp 71-83.

11. See Zuhair Hatab and Abbas Makki, Al-Taqat al-nissa'iya al-arabiya: Dirassa li-awda'iha al-dimografiya wa-l-ijtima'iya wa-I-tanthimiya wa-li ahwaliha al-shakhsiyah (Beirut: Ma'had Al-Inma al-Arabi, 1987), pp 125-168; See Samia Khodr Saleh, "Al-Musharaka al-Siyassiya lil-mar冈a wa-qiwa al-taghayur al-ijtima'i", [Published doctoral thesis] (Cairo: Al-Sadr lil khadamt al-tiba'iya, 1989), p 13. Despite several studies tackling this issue and attempting to critique but in the latter analysis and considering it bases itself on secularist grounds, it was unable to go past concepts and approaches and suggest real alternatives. Take for instance Amal Rassam, "Nahwa itar'amal nathari li-dirassat al-mar囚 a fi-al-'alam al-'arabi in the UNESCO, Social Studies on Women in the Arab World (Beirut: Al-Muassassa Al-Arabiya lil- dirassat wal-nashr wal Tawzi', 1984), p. 223; Souhair Lutfi, "Qira'a fi adabiyat al-musharaka al-siyassiya lil-mar'a al-'arabiya", in Suhair Lutfi (Editor), Al-Mar'a al-'arabiyah wa-I- taghyirat al-ijtima'ia wa-l-thaqafiya (Cairo: UNESCO, 1988), pp. 150-154.

12. See Hisham Sharabi, Al-nitham al-abawi wa ishkaliyat takhalluf al-mujtama' al-'arabi (Beirut: Centre for Arab Unity Studies, 1992); Hisham Sharabi, Al-naqd al-hadhari lil mujtama' al-'arabi fi nihayat al-qarn al-'ishrin (Beirut: Centre for Arab Unity Studies, 1990).

13. The secularist discourse hogs the talking in the name of epistemology and ignores many issues concerning this analysis. Take for instance: Nasr Hamed About Zeid, “Al-Mar'a: Al-Bu'd Al-Mafqud fi-I Khitab al-Dini Al-Mu'asser, Al-Qahira Journal, Issue 123 (February 1993), pp. 16-18.

14. See Sana Al-Masri, Khalf al-hijab (Cairo: Dar Sina, 1989); Leila Abdel Wahab, Ta'thir al-Tayyarat al-Diniya 'ala al-wa'i al-ijtimai' lil mar'a in "Abdel Baqi Al-Hermassi et al, Al-din fi-I mujtama' al-'arabi (Beirut: Centre for Arab Unity Studies, 1990), pp 281-295; May Ghossoub, al-mar'a al-'arabiya wa thukuriyat al-assalah (London: Dar Al-Saqi, 1992).

15. See the following books by Fatima Mernissi specifically Al-harim al-siyassi (English Edition), Women and Islam: A Historical and Theological Enquiry, Mary Jo Lakeland, trans. (Oxford: Blackwell 1994), and Women's Rebellion and Islamic Memory (London: Zed, 1996). Also see Farida Banani, "Al-Nissawiya: Sawtun Masmu'un fi-I niqash al-dini", in Huda alSaddah et al (Editors), Zaman al-nissa' wal thakira al-badilah (Cairo: Multaqa Al-Mar'a wal Thakira, 1998), pp 163-194. 16. On the issue of women in the understanding of the religious reformative movement starting with Sheikh Muhammad Abduh in detail], see Ridwan Al-Sayyid, "Al-Faqih wal-Mar'a: Al-Ru'yah al-islahiyah wa al-Ta'sil Al-ihya'i" in Bahithat Issue 4 (1998/97), pp 88-141.

17. See Muhammad al-Ghazali, Al-isti'mar ahqad wa atma' (Cairo, Al-Khanji Library, 2nd Edition, 1957); Al-Islam al-muftara 'alayh bayn al-shuyu'iyah wal ra'smaliyah (Cairo: Dar Al-Kitab Al-'Arabi, 1951).

18. Thus re-asserting God's will: "believers - men and women - are friends to each other" (Q: Tawbah, 71).

19. See Betty Friedan, Beyond Gender: The New Politics of Work and Family (Baltimore: Johns Hopkins UP, 1998).

20. See Beth Baron, The Woman's Awakening in Egypt: Culture, Society and the Press (New Haven: Yale UP, 1994).

\section{REFERENCES}

Abdelhameed, Q. (1988). Khutub al-sheikh al-ghazali fi shu'un al-din wal-hayat, al-jizi' al-awal Cairo: Dar Al-I'tissam.

Al-Ghazali, M. (1964). Difa'‘an al-'aqida wal shari'a dudd mata'en al-mustashriqin (3rd ed.).Cairo: Dar Al-Kutub Al-Haditha.

Al-Ghazali, M. (1975a). Al-Islam fi wajh al-zahf al-ahmar (5th ed.).Cairo: Dar Al-Mukhtar Al-Islami.

Al-Ghazali, M. (1975b). Qathaif al-haq [XXX]. Beirut: Al-Maktaba Al-'Asriyah.

Al-Ghazali, M. (1977). Haqiqat al-qawmiyah al-'arabiya wa usturat al-ba'th al-'arabi (3rd ed.). Cairo: Dar Al-Kutub Al-Haditha.

Al-Ghazali, M. (1981). Dustur al-wehda al-thaqafiya bayna al-muslimin. Cairo: Dar Al-Ansar.

Al-Ghazali, M. (1983a). Al-Islam wa-l-taqat al-Mu'attalah (4th ed.). Cairo: Dar Al-Kotob Al-Islamiyah.

Al-Ghazali, M. (1983b). Huquq al-insan bayna ta'alim al-Islam wa $\bigotimes$ i'lan al-umam al-muttahidah (3rd ed.).Cairo: Dar Al-Kutub Al-Islamiyah.

Al-Ghazali, M. (1983c). Layssa min al-Islam. Cairo: Dar Al-Shuruq.

Al-Ghazali, M. (1984a). Ma'at su'al 'an al-islam, al-juzu' al-thani. Cairo: Dar Thabet.

Al-Ghazali, M. (1984b). Min ma'alem al-haq fi kifahina al-islami al-hadith (4th ed.). Cairo: Dar Al-Sahwa. 
Al-Ghazali, M. (1985). Al-da'wa al-islamiyya tastaqbil qarnaha al-khamis 'ashar. Cairo: Maktabat Wehbe.

Al-Ghazali, M. (1987a). Al-ghazu al-thaqafi yamtaddu fi faraghina. Cairo: Dar Al-Sahwa.

Al-Ghazali, M. (1987b). Al-tariq min huna. Cairo: Dar Al-Basheer.

Al-Ghazali, M. (1989). Al-sunnah al-nabawiya bayna ahl al-figh wa ahl al-hadith. Cairo: Dar Al-Shuruq. Al-Ghazali, M. (1990a). Hatha dinuna (2nd ed.). Cairo, Dar Al-Shuruq.

Al-Ghazali, M. (1990b). Qadaya al-mar'a bayna al-taqalid al-rakida wa-l-wafida. Cairo: Dar Al-Shuruq.

Al-Ghazali, M. (1991a). Kifah din (5th ed.). Cairo: Dar Al-Kutub al-Islamiyah.

Al-Ghazali, M. (1991b). Sayhat tahthir min du'at at-tansir. Cairo: Dar Al-Sahwa.

Al-Ghazali, M. (1991c). Turathuna al-fikri fi mizan al-shari' wa-l'aql. Cairo: Dar al-shuruq.

Al-Ghazali, M. (1994). Ma'rakat al-mushaf fi-I'alam al-islami (2nd ed.). Cairo: Dar Al-Kutub al-Haditha.

Al-Qaradawi, Y. (1977). Al-khassa'is al-'ammah lil-Islam (10th ed.).Cairo: Maktabat Wehbe.

Al-Qaradawi, Y. (1990). Al-muqaddimah [The introduction]. In A. Abou Sheqa (ed.), Tahrir al-mar'a fi 'asr al-rissalah, al-jizi' al-awal (10th ed.). Kuwait: Dar Al-Qalam.

Al-Qaradawi, Y. (1991). Awlawiyat al-haraka al-islamiya fi-I-marhala al-qadimah (12th ed.). Beirut: Dar Al-Rissalah.

Al-Qaradawi, Y. (1992a). Al-marja'iah al-'ulia fi-l islam lel qur'an wal sunnah: Dawabet wa mahathir fi al-fahm wal tafseer. Cairo: Maktabat Wehbe.

Al-Qaradawi, Y. (1992b). Liqa'at wa muhawarat hawla qadaya al-islam al-mu'asse. Cairo: Maktabat Wehbe.

Al-Qaradawi, Y. (1992c). Muslimat al-ghad (1st ed.). Cairo: Dar Al-Wafa'.

Al-Qaradawi, Y. (1993a). Fatawi mu'assirah: Min hadyi al-islam, al-jizi' al thani (2nd ed.). Cairo: Dar AlWafa'.

Al-Qaradawi, Y. (1993b). Malameh al-mujtama' al-muslim allathi nanshuduh [Features of the Muslim community we desire] (10th ed.).Cairo: Maktabat Wehbe.

Al-Qaradawi, Y. (1995). Al-Islam hadarat al-ghad (1st ed.). Cairo: Maktabat Wehbe.

Baron, B. (1994). The woman's awakening in Egypt: Culture, society and the press. New Haven: Yale University Press.

Friedan, B. (1998). Beyond gender: The new politics of work and family. Baltimore: Johns Hopkins University Press.

Hussein, A., et al. (1993). Al-huquq al-qanuniah lil mar'a al-arabiya bayn al-nathariya wal tatbiq. Cairo: D.N.

Sharabi, H. (1992). Al-nitham al-'abawi wa ishkaliyat takhalluf al-mujtama' al-'arabi. Beirut: Centre for Arab Unity Studies. 